\title{
PRIGOVOR KORUPCIJE I ODGOVORNOST DRŽAVE U MEĐUNARODNOM INVESTICIJSKOM PRAVU ZA KORUPTIVNO POSTUPANJE SVOJIH SLUŽBENIKA
}

DOI: $10.3935 /$ zpfz.69.2.02

Izvorni znanstveni rad Primljeno: rujan 2018.

U radu se analizira primjena tzv. prigovora korupcije u međunarodnim investicijskim arbitražama kojim se sve više koriste tužene države kao načinom za izbjegavanje odgovornosti. Posebice se upozorava na problem asimetričnog pristupa odgovornosti države i investitora. Naime, prema izgrađenoj arbitražnoj praksi, investitor uvijek odgovara za sudjelovanje u korupciji prilikom poduzimanja investicije, a država ne odgovara jer je praksa izgradila stav da postupanja državnih službenika koji sudjeluju u takvoj korupciji nisu pripisiva državi. Takav stav suprotan je načelima međunarodnog prava o odgovornosti država. Prigovor korupcije stavlja se u kontekst odgovornosti države po međunarodnom pravu, pa se nude moguća rješenja postojeće asimetrije kroz izmjene medunarodnih investicijskih ugovora te kroz primjenu instituta prě̌utnog prihvaćanja.

Ključne riječi: međunarodna investicijska arbitraža, prigovor korupcije, odgovornost države, pripisivost, prešutno prihvaćanje

\section{UVOD}

Odgovornost države za postupke svojih službenika kao i za druge subjekte koji rade u njezino ime ili su pod državnim upravljanjem ili kontrolom temeljno je načelo međunarodnih odnosa, pa tako i međunarodnog prava, uključujući i

* Dr. sc. Orsat Miljenić, zastupnik i predsjednik Odbora za pravosuđe Hrvatskog sabora, Hrvatski sabor, Trg Sv. Marka 6, Zagreb; orsatmiljenic@gmail.com;

ORCID ID: orcid.org/0000-0002-9191-3344 
pravo koje uređuje strane investicije. ${ }^{1}$ Načelno je jednak i pristup odgovornosti investitora za postupanje njegovih zaposlenika odnosno agenata.

Međutim, u praksi međunarodne investicijske arbitraže (dalje u tekstu: MIA) pravila o odgovornosti za postupanje službenika odnosno zaposlenika različito se primjenjuju u odnosu na državu i u odnosu na investitora kada je u pitanju korupcija ${ }^{2}$ kod poduzimanja investicije. U kontekstu MIA-e $\mathrm{e}^{3}$ tzv. prigovor korupcije (corruption defense $)^{4}$ označava prigovor tuženika - države primateljice investicije, da je tužitelj - investitor, prilikom poduzimanja investicije dao mito njezinim službenicima te da zbog toga njegova investicija ne uživa zaštitu na temelju investicijskog ugovora. ${ }^{5}$ Prihvati li se prigovor korupcije, država primateljica investicije može, upravo zahvaljujući tome što su njezini službenici primili mito, u potpunosti izbjeći odgovornost za povrede prava investitora koja im je zajamčila investicijskim ugovorima. Nasuprot tome, investitor koji je sudjelovao u istom koruptivnom činu davanjem mita istim tim državnim službenicima ostaje u potpunosti nezaštićen. Prigovor korupcije postaje tako presudan za ishod spora jer ako se dokaže korupcija, tužba biva u pravilu odbačena zbog nenadležnosti arbitražnog suda, što za investitora zapravo znači da nema učinkovitog sredstva za zaštitu svojih prava. ${ }^{6}$

1 Vidi opširnije u: Llamzon, P., A., Corruption in International Investment Arbitration, Oxford University Press, Oxford, 2014., str. 238.

2 Korupcija se u kontekstu međunarodnog investicijskog prava može definirati kao "svjesna primjena ili odbijanje primjene zakona na način koji je u korist privatnog interesa na štetu javnih potreba.” (Llamzon, op. cit. u bilj. 1, str. 22). Sve citate u tekstu preveo je autor.

3 U radu se razlikuju investicijske arbitraže - one koje se temelje na investicijskim međudržavnim ugovorima, i trgovačke arbitraže - one koje se temelje na trgovačkim ugovorima, u kojima država može, ali i ne mora biti jedna od stranaka. Suglasnost za arbitražno rješavanje sporova kod investicijskih arbitraža daje se u međudržavnim (bilateralnim ili multilateralnim ugovorima) čije stranke nisu investitori, dakle, ugovorom se daje ponuda za arbitražu trećoj osobi (investitoru) koja se smatra prihvaćenom podnošenjem tužbe arbitražnom sudu (arbitration without privity). Kod trgovačke arbitraže, bez obzira na to je li država jedna od stranaka, arbitražni ugovor odnosno klauzula sklapa se između stranaka.

4 U literaturi na engleskom jeziku uobičajeno se upotrebljava izraz corruption defense, a u ovom radu upotrebljavat će se izraz prigovor korupcije.

5 Kako je naveo Losco, prigovor korupcije podsjeća na common law doktrinu "prljavih ruku" koja sprečava tužitelja u ostvarenju tužbenog zahtjeva ako je i on sam kriv za neku nezakonitost u odnosu na predmet spora (Losco, A. M., Streamlining the Corruption Defense: A Proposed Framework for FCPA-ICSID Interaction, Duke Law Journal, vol. 63, br. 5, 2014., str. 1215).

6 Vidi opširnije u: Llamzon, A.; Sinclair, C. A., Investor Wrongdoing in Investment Arbitration: Standards Governing Issues of Corruption, Fraud, Misrepresentation and Other 
Takav pristup ilustrira stav arbitražnog suda u predmetu Metal-Tech protiv Uzbekistana koji je zaključio da se

"prava investitora u odnosu na državu primateljicu investicije, uključujući i pravo na pristup arbitraži, ne mogu štititi jer je investicija "zagađena" nezakonitim postupanjima, konkretno korupcijom (investitora, op. a.). Pravo je jasno, i to s razlogom, da u takvim slučajevima (kod davanja mita od strane investitora, op. a.) investitor gubi pravo na zaštitu te da slijedom toga država primateljica investicije izbjegava bilo kakvu moguću odgovornost."’

Temelj za ovakvu odluku bilo je to da je država primateljica, po utvrđenju arbitražnog suda, dokazala da je investitor poduzeo investiciju dajući mito, među ostalim i njezinim službenicima $(\text { sic! })^{8}$ te da stoga nema pravo na zaštitu jer arbitražni sud nema nadležnost za postupanje u ovom predmetu ${ }^{9} \mathrm{~s}$ obzirom na to da je investitor postupao suprotno zakonima države primateljice investicije.

Očito je postojanje asimetrije u odgovornosti (attribution asymmetry) za korupciju između investitora i država primateljica investicije. Naime, kada investitorov zaposlenik ili agent da mito državnom službeniku kako bi mu on omogućio ili olakšao poduzimanje investicije, investitor odgovara za postupanje svojeg zaposlenika, međutim, prema do sada izgrađenoj arbitražnoj praksi, država ne odgovara za koruptivno postupanje svojih službenika, "korupcija na strani državnog službenika se ne pripisuje državi primateljici investicije". ${ }^{10}$ Takav asimetričan, nepovoljan pristup samo za jednu stranu - investitora, posebno je dvojben kad je riječ o korupciji jer, za razliku od drugih oblika nezakonitosti, npr. prevare, kod korupcije je uvijek "potrebno dvoje za tango"ll, odnosno u njoj moraju nužno sudjelovati i investitor i državni službenik.

Investor Misconduct, u: van den Berg, A. J. (ur.), Legitimacy: Myths, Realities, Challenges, ICCA Congress Series, vol. 18, Kluwer Law International, Alphen aan den Rijn, 2015., str. 451.

7 Metal-Tech Ltd. v. Republic of Uzbekistan, ICSID Case No. ARB/10/3, pravorijek od 4. 10. 2013., para. 422, https://www.italaw.com/sites/default/files/case-documents/ italaw3012.pdf (1. lipnja 2018.).

8 Ibid., para. 372.

$9 \quad$ Ibid., para. 389.

10 Klaw, W. B., State Responsibility for Bribe Solicitation and Extortion: Obligations, Obstacles and Opportunities, Berkeley Journal of International Law, vol. 33, br. 1, 2015., str. 96.

11 Alekhin, S.; Shmatenko, L., Corruption in Investor-State Arbitration - It Takes Two to Tango, u: Asoskov, A. V. et al. (ur.), New Horizons of International Arbitration, Issue 4, 
Iz analizirane arbitražne prakse proizlazi da je ishodište takve asimetrije u odgovornosti, pa time i moguće rješenje, u izostanku primjene načela međunarodnog prava o odgovornosti država za protupravne čine što rezultira "očitom asimetrijom koja nije opravdana tradicionalnim pravilima o pripisivosti”. ${ }^{12} \mathrm{U}$ ovom se radu stoga obrađuju pravila međunarodnog prava o odgovornosti država koja se primjenjuju u MIP-u (2.), stajališta arbitražnih sudova u međunarodnim investicijskim sporovima o prigovoru korupcije (3.), stajališta arbitražnih sudova o odgovornosti država kod isticanja prigovora korupcije (4.) te se nude moguća rješenja kako bi se spriječila asimetrija u odgovornosti (5.).

\section{PRIMJENA PRAVILA MEĐUNARODNOG PRAVA O ODGOVORNOSTI DRŽAVA U MEĐUNARODNOM INVESTICIJSKOM PRAVU}

Po međunarodnom pravu "međunarodnopravna odgovornost države za protupravno djelovanje postoji ako se djelovanje države sastoji od čina ili propusta koji se mogu pripisati državi i ako takvo djelovanje tvori povredu međunarodne obveze". ${ }^{13}$ Međutim, prije razrade međunarodnopravne odgovornosti države za protupravno djelovanje postavlja se pitanje primjenjivosti međunarodnog prava u MIP-u te, s time u vezi, i pitanje međunarodnopravnog subjektiviteta ${ }^{14}$ investitora te naravi samih međunarodnih investicijskih ugovora.

Collection of Articles, Association of Private International and Comparative Law Studies, Moskva, 2018., str. 176.

12 Drude, J., Fiat iustitia, ne pereat mundus: A Novel Approach to Corruption and Investment Arbitration, Journal of International Arbitration, vol. 35, br. 6, 2018., str. 688.

13 Seršić, M., Međunarodnopravna odgovornost država: pitanje krivnje i dužne pažnje, Zbornik Pravnog fakulteta u Zagrebu, vol. 49, br. 1, 1999., str. 5.

14 Neki autori, npr. Higgins, smatraju kako je i podjela na "subjekte" i "objekte" međunarodnog prava pogrešna te kako je pravilno govoriti o "sudionicima" (participants) u međunarodnim pravnim procesima, dok drugi, npr. Crawford, ustraju na takvoj podjeli s tim da su prema njihovu mišljenju jedini pravi subjekti države i organizacije koje one stvore (npr. OUN), dok svi drugi sudionici mogu imati samo djelomični subjektivitet (vidi opširnije u: Alvarez, J. E., Are Corporations Subjects of International Law, Santa Clara Journal of International Law, vol. 9, br. 1, 2011., str. 8.). 


\subsection{Primjenjivost međunarodnog prava $\mathbf{u}$ međunarodnom investicijskom pravu}

MIP se temelji na mreži bilateralnih i multilateralnih investicijskih ugovora koje sklapaju države na koje se odnose pravila i načela međunarodnog prava te na koje investitori nemaju izravnog utjecaja jer niti sudjeluju u njihovu sklapanju niti su stranke tih ugovora. Stoga je priroda MIP-a na neki način hibridna - ono uređuje ne samo pravne odnose između država (one čije državljanstvo ima investitor i one u kojoj se poduzima investicija) nego i između države i pojedinca, odnosno države domaćina i investitora. ${ }^{15}$ Iako su međudržavni, takvi ugovori imaju za cilj upravo zaštitu investitora i njihovih investicija, što ostvaruju kroz utvrđivanje određenih standarda njihove zaštite uz istodobno ustanovljavanje mehanizma za rješavanje sporova, odnosno davanje mogućnosti izravne zaštite njihovih prava investitorima. Suvremeno međunarodno investicijsko pravo predstavlja primjer jedne od grana međunarodnog javnog prava koje daje i materijalna i postupovna prava fizičkim i pravnim osobama (uz npr. međunarodno humanitarno pravo), čime im daje status “djelomičnih subjekata međunarodnog prava" ${ }^{16}$ Stoga je kod investicijskih arbitraža koje se temelje na međunarodnim ugovorima međunarodno javno pravo neizbježni dio primjenjivog prava. ${ }^{17}$

Sklapanje međunarodnih investicijskih ugovora i na njima utemeljena arbitražna praksa potaknula je i utjecala na razvoj cijelog međunarodnog javnog prava, posebice dajući investitorima “široka subjektivna prava i izravni pristup međunarodnom načinu rješavanja sporova”. ${ }^{18}$ Po međunarodnim investicijskim ugovorima investitori ne samo da stječu prava različita od onih koje imaju države kao članice tih ugovora, već im se u pravilu omogućuje i izravno štititi svoja prava na međunarodnoj razini i to u odnosu na države ${ }^{19}$,

15 O tome više u: Wittich, S., State Responsibility, u: Bungenberg, M. et al. (ur.), International Investment Law, Nomos, Baden-Baden, 2015., str. 37 - 38.

16 Hofmann, R., The Protection of Individuals under Public International Law, u: Bungenberg, M. et al. (ur.), International Investment Law, Nomos, Baden-Baden, 2015., str. $50-51$.

17 Llamzon, A., On Corruption's Peremptory Treatment in International Arbitration, u: Baizeau, D.; Kreindler, R. (ur.), Addresing Issues of Corruption in Commercial and Investment Arbitration, Dossiers of the ICC Institute of World Business law, vol. 13, Kluwer Law International, Alphen aan den Rijn, 2015., str. 35.

18 Bungenberg, M.; Griebel, J.; Hobe, S.; Reinisch, A., General Introduction to International Investment Law, u: Bungenberg, M. et al. (ur.), International Investment Law, Nomos, Baden-Baden, 2015., str. 1.

19 Alvarez, op. cit. u bilj. 14, str. 12. 
čime se prvi put "odnos između država i pojedinca može smatrati na neki način horizontalnim". ${ }^{20}$

Izgradila su se tri pristupa odgovoru na pitanje jesu li strani investitori subjekti međunarodnog prava. Prema jednom pristupu riječ je o izvedenim pravima, naime, i materijalna i postupovna prava iz investicijskih ugovora prava su država ugovornica na koja se investitor može pozivati samo kao ovlaštenik svoje države protiv države primateljice investicije. ${ }^{21}$ Kako navodi Crawford, prava koja se u investicijskim ugovorima daju investitorima "na neki način institucionaliziraju i daju snagu (umjesto da ga zamijene) sustavu diplomatske zaštite ${ }^{22}$ i, sukladno Mavrommatis formuli, to su prava države, a ne investitora". ${ }^{23}$ Drugi pristup je onaj prema kojem činjenica da investicijski ugovori kojima se investitorima daju određena materijalna i postupovna prava koja mogu izravno provoditi pokazuje da su "države ugovornice željele stvoriti osnovu za individualna i izravna prava investitora". ${ }^{24}$ Ovime se, dakle, daje jedna vrsta subjektiviteta investitorima u međunarodnom pravu. Kako je to naveo arbitražni sud u predmetu SGS protiv Filipina, "po suvremenom međunarodnom pravu ugovori mogu davati prava, kako materijalna, tako i postupovna, pojedincima”, pri čemu je relevantno da je riječ o ostvarenju nekog javnog interesa, u ovom slučaju to je interes privlačenja stranih investicija i kroz to gospodarski razvoj države domaćina, zapošljavanje i

20 Spiermann, O., Twentieth Century Internationalism in Law, European Journal of International Law, vol. 18, br. 5, 2007., str. 811.

21 Braun, T. R., Globalization-Driven Innovation: The Investor as a Partial Subject in Public International Law; An Inquiry into the Nature and Limits of Investor Rights, Journal of World Investment and Trade, br. 15, 2014., str. 86.

22 Op. a.: Diplomatska zaštita znači intervenciju, diplomatskim ili drugim sredstvima mirnog rješavanja sporova, jedne države prema drugoj državi zbog međunarodno protupravnog čina koji je ta druga država počinila prema fizičkoj ili pravnoj osobi koja je državljanin, odnosno ima državnu pripadnost države koja pruža zaštitu. (Seršić, M., Diplomatska zaštita, Zbornik Pravnog fakulteta u Zagrebu, vol. 62, br. 1-2, 2012., str. 735.)

23 Crawford, J., The ILC's Articles on Responsibility of States for Internationally Wrongful Acts: A Retrospect, The American Journal of International Law, vol. 96, br. 4, 2002. str. 887 - 888. Tzv. Mavrommatis formulu definirao je Stalni sud međunarodne pravde u predmetu Mavrommatis kao "preuzimanje slučaja nekog od njezinih drŽavljana i pribjegavanjem diplomatskoj akciji ili međunarodnom sudskom postupku u njegovo ime država zapravo brani svoje vlastito pravo, pravo da osigura, u osobi svojeg državljanina, poštovanje pravila međunarodnog prava." (Mavrommatis Palestine Concessions (Grčka v. Ujedinjeno Kraljevstvo), Permanent Court of International Justice Reports, Series A, br. 2, str. 12).

24 Braun, op. cit. u bilj. 21, str. 88. 
sl. ${ }^{25}$ Postoji i treći pristup koji na neki način predstavlja spoj ovih dvaju pristupa i prema kojem se razlikuju materijalna i postupovna prava. Materijalna prava, odnosno standardi zaštite investitora koji su sadržani u investicijskom ugovoru ostaju na razini država članica, dakle investitor ih konzumira kao ovlaštenik svoje države, dok postupovna prava, konkretno pravo na arbitražu odnosno na izravnu tužbu protiv države domaćina predstavlja izravno pravo investitora nakon što podnese obavijest o tužbi. ${ }^{26}$ Čnjenica da investitor ima potpunu kontrolu nad svojom tužbom upućuje na to da prava koja daju suvremeni investicijski ugovori pripadaju investitorima, a ne državama, pa bi, kako navodi Spiermann, bilo vrlo teško zauzeti stav da "bilateralni investicijski ugovori (dalje u tekstu: BIU) ne daju prava investitorima kao da su subjekti međunarodnog prava”. ${ }^{27}$ Stoga se investicijske ugovore može tumačiti na način da oni predstavljaju "ugovore po međunarodnom pravu koji daju izravna prava pojedincima (time i investitorima, op. a.)" ${ }^{28}$ Arbitražni sud u predmetu Plama protiv Bugarske, raspravljajući o arbitražnoj klauzuli iz Ugovora o energetskoj povelji ${ }^{29}$, utvrdio je kako upravo mogućnost izravnog obraćanja arbitraži za investitore "označava novi korak u njihovoj tranziciji iz objekata u subjekte međunarodnog prava”. ${ }^{30}$ Davanjem ovakvih prava investitorima oni postaju “djelomični subjekti” međunarodnog prava, naime, oni dobivaju samo ona prava koja su im potrebna kako bi zaštitili svoju investiciju, dakle države daju investitorima samo onoliko subjektiviteta u međunarodnom pravu koliko im je funkcionalno potrebno da bi se zaštitili međunarodni odnosi na području investicija.

25 SGS Société Générale de Surveillance S.A. v. Republic of the Philippines, ICSID Case No. ARB/02/6, Odluka o prigovorima na nadležnost, 29. 1. 2004. https://www.italaw. $\mathrm{com} /$ sites/default/files/case-documents/ita0782.pdf (19. ožujka 2019.).

26 Braun, op. cit. u bilj. 21, str. $88-89$.

27 Spiermann, O., Individual Rights, State Interests and the Power to waive ICSID Jurisdiction under Bilateral Investment Treaties, Arbitration International, vol. 20, br. 2, 2004., str. 185.

28 Braun, op. cit. u bilj. 21, str. 98.

29 Ugovor o energetskoj povelji (Energy Charter Treaty) je međunarodni investicijski ugovor na području energetike sklopljen 1994., koji je stupio na snagu u travnju 1998. godine. Članice Ugovora su 51 država i međunarodna organizacija i on predstavlja najkorišteniji investicijski ugovor u međunarodnoj investicijskoj arbitraži. Republika Hrvatska pristupila je Ugovoru u prosincu 1997. (Narodne novine, Međunarodni ugovori, br. 15/1997).

30 Plama Consortium Limited v. Republic of Bulgaria, ICSID Case No. ARB/03/24, Odluka o nadležnosti od 8. 2. 2005., para. 141., https://www.italaw.com/sites/default/files/ case-documents/ita0669.pdf (18. ožujka 2019.). 


\subsection{Nacrt članaka o odgovornosti država za međunarodno protupravne čine}

Komisija za međunarodno pravo (dalje u tekstu: KMP) ${ }^{31}$ izradila je dokument pod nazivom Nacrt članaka o odgovornosti država za međunarodno protupravne čine s komentarom (2001.; dalje u tekstu: Nacrt članaka). ${ }^{32}$ Nacrt članaka primjenjiv je na sve oblike rješavanja međunarodnih sporova, uključujući i međunarodne investicijske sporove koji se rješavaju pred međunarodnim arbitražama. Prvi dio Nacrta članaka odnosi se na sve moguće obveze odgovorne države, bez obzira na to koje je prirode entitet na koji se odnose te obveze, iz čega nedvojbeno proizlazi da se Nacrt članaka odnosi i na odgovornost država za povrede prava investitora koja im daju međunarodni ugovori te da su primjenjivi u MIA-i. ${ }^{33}$ Kako navode Crawford i Olleson:

"zajedno s pravom ugovora, pravila o odgovornosti država (Nacrt članaka, op. a.) predstavljaju temeljni međunarodnopravni okvir za odlučivanje o sporovima koji se odnose na povredu međunarodne obveze po nekom od instrumenata koji uređuju međunarodnu zaštitu investicija pa kao takav uvjetuje pitanja (pripisivost, povredu, obeštećenje) na koja treba odgovoriti kako bi se takvi sporovi mogli riješiti." ${ }^{34}$

Iako Nacrt članaka ne predstavlja "ugovor" koji bi bio na snazi, postoji, kako to navodi Hobér, "opće suglasje da Nacrt članaka točno odražava međunarodno običajno pravo o odgovornosti država”. ${ }^{35}$ Nacrt članaka uobičajeno se smatra

31 Komisiju za međunarodno pravo ustanovila je Opća skupština Ujedinjenih naroda 1947. kao svoje pomoćno tijelo s ciljem provedbe jedne od funkcija Opće skupštine UN-a - proučavanja i davanja preporuka u svrhu "poticanja progresivnog razvoja međunarodnog prava i njegove kodifikacije.” (čl. 13. st. la Povelje Ujedinjenih naroda, dostupno na http://www.mvep.hr/CustomPages/Static/HRV/Files/ugovori/ povelja_un_hr.pdf, 8. ožujka 2019.). Komisija je počela s radom 1949. i do sada je održala 70 sjednica. Članove Komisije bira Opća skupština UN-a, a Komisija zasjeda svake godine u Ženevi.

32 O izradi Nacrta članaka vidi opširnije u: Wittich, S., The International Law Commission's Articles on the Responsibility of States for Internationally Wrongful Acts Adopted on Second Reading, Leiden Journal of International Law, vol. 15, br. 4, 2002., str. 891 - 920.

33 Crawford, J.; Olleson, S., The Application of the Rules of State Responsibility, u: Bungenberg, M. et al. (ur.), International Investment Law, Nomos, Baden-Baden, 2015., str. 416. Ibid., str. 441.

35 Hobér, K., State Responsibility and Investment Arbitration, Journal of International Arbitration, vol. 25, br. 5, 2008., str. 548. 
kodifikacijom međunarodnog prava na kojoj su mnogi arbitražni sudovi temeljili svoje odluke. ${ }^{36}$ Kako je to npr. naveo arbitražni sud u predmetu Jan de Nul protiv Egipta, prilikom odlučivanja o pripisivosti po međunarodnom pravu treba primjenjivati Nacrt članaka jer on predstavlja "kodifikaciju međunarodnog običajnog prava". ${ }^{37}$ Ovdje treba napomenuti da Nacrt članaka nije pisan u formi međunarodnog ugovora niti je formalno usvojen ili ponuđen na potpisivanje, međutim, unatoč tome, međunarodni sudovi ga primjenjuju u potpunosti tretirajući ga kao "funkcionalni ekvivalent međunarodnom običajnom pravu o odgovornosti država". ${ }^{38}$

Bez obzira na to smatramo li investitora subjektom međunarodnog prava ili ne, odnosno bez obzira na to zauzme li se stajalište da je riječ o izvornim ili izvedenim pravima, nesporno je da investitor ima određena materijalna prava prema investicijskim ugovorima te da mu ti ugovori omogućuju izravnu zaštitu tih prava pred međunarodnim arbitražama. Odgovornost država na području MIP-a predstavlja samo jednu od vrsta odgovornosti država po međunarodnom javnom pravu. ${ }^{39}$

\subsection{Pretpostavke za odgovornost države}

U čl. 2. Nacrta članaka navode se dva zahtjeva za postojanje odgovornosti države: "međunarodno protupravni čin države postoji kad se ponašanje države sastoji od djelovanja ili propusta koji se može pripisati državi po međunarodnom pravu i kada takvo ponašanje tvori povredu međunarodne obveze države". ${ }^{40}$ Riječ je o kumulativnim zahtjevima, dakle ne postoji "hijerarhija" među njima, iako redoslijed kojim su navedeni upućuje na to da bi utvrđivanje odgovornosti države trebalo krenuti od toga je li određeno postupanje pripisivo državi, pa tek ako se to utvrdi, prijeći na utvrđivanje je li riječ o povredi međunarodne obveze države. ${ }^{41}$ Pritom je važno napomenuti kako "identitet entiteta koji tvrdi da je

36 Vidi opširnije u: Salacuse, J. W., The Law of Investment Treaties, Oxford University Press, Oxford, 2015., str. $441-442$.

37 Jan de Nul NV and Dredging International NV v. Arab Republic of Egypt, Case No. ARB/04/13, Decision on jurisdiction, 16. 6. 2006., para. 89, https://www.italaw. com/sites/default/files/case-documents/ita0439.pdf (10. rujna 2018).

38 Vidi opširnije u: Llamzon, op. cit. u bilj. 1, str. 244.

39 Više u: Crawford; Olleson, op. cit. u bilj. 33, str. 412 - 413.

40 Tekst Nacrta članaka na engleskom jeziku dostupan je na: http://legal.un.org/ilc/ texts/instruments/english/commentaries/9_6_2001.pdf (1. lipnja 2018.).

41 Kako je to utvrdio Međunarodni sud u predmetu Diplomatic and Consular Staff in Teheran: "Prvo se mora utvrditi do koje se mjere, pravno, čini koji su u pitanju mogu 
država počinila međunarodno protupravni čin treba biti nebitan za odgovor na pitanje je li određeni čin pripisiv državi po međunarodnom pravu". ${ }^{42}$

U nastavku poglavlja razmotrit će se djelovanje ili propuštanje koje se prema međunarodnom pravu može pripisati državi (2.3.1.) i djelovanje ili propuštanje koje predstavlja povredu međunarodne obveze države (2.3.2.).

\subsubsection{Djelovanje ili propuštanje koje se prema međunarodnom pravu može pripisati državi}

Razmatrajući pitanje prigovora korupcije u kontekstu pripisivosti određenog djelovanja ili propuštanja državi po međunarodnom pravu potrebno je razmotriti može li se mito koje primi državni službenik pripisati državi općenito (2.3.1.1.) te $\mathrm{u}$ svezi s tim je li državni službenik primio mito u privatnom ili javnom svojstvu (2.3.1.2.).

\subsubsection{Pripisivanje državi primanja mita od strane državnih službenika}

Da bi država bila međunarodno odgovorna zbog određenog postupanja ili propusta, mora biti riječ o postupanju ili propustu osoba čija su djelovanja ili propuštanja pripisiva državi. Kako je to utvrdio Stalni sud međunarodne pravde, "države mogu djelovati jedino po i putem njihovih agenata i predstavnika". ${ }^{43} \mathrm{U}$ međunarodnom pravu države su odgovorne za međunarodne protupravne čine koje počine njihovi državni službenici. Pri tome je irelevantno koju funkciju imaju ti državni službenici i koji je njihov rang kao i to koji su bili njihovi motivi i razlozi, čak i ako je riječ o zloupotrebi ovlasti, za takvo postupanje dok god djeluju pod okriljem svoje službene dužnosti odnosno položaja.

smatrati pripisivima Iranu. Drugo se mora razmotriti njihova usklađenost ili neusklađenost s obvezama koje ima Iran po ugovorima koji su na snazi ili po drugim primjenjivim pravilima međunarodnog prava." (United States Diplomatic and Consular Staff in Tehran (USA v. Iran)), Judgment, I. C. J. Reports, 1980., para. 56, https:// www.icj-cij.org/files/case-related/64/064-19800524-JUD-01-00-EN.pdf (1. srpnja 2018.).

42 Crawford, R. J.; Mertenskötter, P., The Use of the ILC's Attribution Rules in Investment Arbitration, u: Kinnear, M. et al. (ur.), Building International Investment Law: The First 50 Years of ICSID, Kluwer Law International, Alphen aan den Rijn, 2015., str. 40.

43 Stalni sud međunarodne pravde, German Settlers in Poland, Advisory Opinion, 1923, P. C. I. J. Ser. B., No. 6, str. 22, https://www.italaw.com/sites/default/files/case-documents/ita0726.pdfwww.icj-cij.org/files/permanent-court-of-international-justice/serie_B/B_06/Colons_allemands_en_Pologne_Avis_consultatif.pdf (1. srpnja 2018.). 
Tako i prema Nacrtu članaka o ocjeni djelovanja organa države ni djelovanje ultra vires, ni motivi, ni zloupotreba ovlasti od strane javnog službenika ne izoliraju državu od odgovornosti za njihove nezakonite postupke dok god taj službenik djeluje s pozicije vlasti ili pod krinkom vlasti. ${ }^{44}$ Klasični primjer je slučaj Caire u kojem su dva meksička časnika otela pa zatim i ubila francuskog državljanina nakon što nisu uspjeli iznuditi novac od njega. Francusko-meksička komisija za rješavanje sporova zaključila je kako postupanje "dvaju časnika, čak i ako bi se smatralo da su postupali izvan njihove nadležnosti ... pa čak ako su njihovi nadređeni zapovjedili suprotno, predstavlja odgovornost države jer su djelovali pod okriljem njihova statusa kao časnika i upotrijebili su sredstva koja su im dana na raspolaganje upravo na temelju tog statusa". ${ }^{45}$

Kod razmatranja pitanja pripisivosti u praksi MIP-a arbitražni sudovi u pravilu su se pozivali na Nacrt članaka. ${ }^{46}$ Tako je i u MIP-u nesporno da država odgovara za postupanje svojih službenika, npr. provedba nezakonitog izvlaštenja, i pri tome se ne može braniti da je takav službenik time djelovao izvan svojih ovlasti ili nezakonito. Arbitražni sud je tako u predmetu Siag protiv Egipta zaključio kako je opće načelo međunarodnog prava da će se "postupanje bilo kojeg državnog tijela smatrati činom države po međunarodnom pravu čak i ako prekorači svoje ovlasti". ${ }^{47}$ Kako navode Dolzer i Scheuer, "država odgovara za postupke svojih tijela čak i kad su oni u suprotnosti sa zakonom, pa čak i kada su suprotni uputama". ${ }^{48}$ Slično je i u predmetu SPP protiv Egipta ${ }^{49}$ arbitražni

44 Čl. 4. Nacrta članaka definira djelovanje države: "Djelovanje bilo kojeg tijela države smatrat će se činom te države po međunarodnom pravu, bilo da je riječ o tijelu koje obavlja zakonodavnu, izvršnu, sudbenu ili neku drugu funkciju, i to bez obzira koju poziciju ima u državnoj organizaciji i bez obzira na njegov karakter tijela središnje države ili neke teritorijalne jedinice te države. Tijelo uključuje sve osobe ili entitete koji imaju takav status sukladno unutrašnjem pravu te države”. Opširnije o ovoj temi vidi u komentarima uz ovaj članak.

45 Citirano prema: Yearbook of the International Law Commission 2001, sv. 2, dio 2, United Nations, New York - Geneva, 2007., str. 46.

46 Crawford, J., Investment Arbitration and ILC Articles on State Responsibility, ICSID Review - Foreign Investment Law Journal, vol. 25, br. 1, 2010., str. 133.

47 Elie George Siag and Clorinda Vecchi v. The Arab Republic of Egypt, ICSID Case No. ARB/05/15, pravorijek od 1. 6. 2009., para. 195, https://www.italaw.com/sites/ default/files/case-documents/ita0786_0.pdf (1. lipnja 2018.).

48 Dolzer, R.; Schreuer, C., Principles of International Investment Law, 2nd ed., Oxford University Press, Oxford, 2012., str. 217.

49 Southern Pacific Properties (Middle East) Limited v. The Arab Republic of Egypt, ICSID predmet broj ARB/84/3, pravorijek od 20. 5. 1992., para. 83, https://www.italaw. com/sites/default/files/case-documents/italaw6314_0.pdf (17. rujna 2018.). 
sud utvrdio kako "bilo da su legalni po egipatskom pravu ili da nisu, postupci koji su u pitanju bili su postupci egipatskih vlasti”, a u predmetu Kardassopoulos protiv Gruzije arbitražni sud naglasio je kako je država odgovorna za postupanje svojih tijela i kad ona postupaju ultra vires ili suprotno zakonu. ${ }^{50}$

Kad je u pitanju korupcija, dakle mito koje primi državni službenik, Crawford smatra kako na temelju općeg prava o odgovornosti država koruptivno postupanje visokih državnih službenika treba pripisati državi: "Što je moćniji službenik u unutrašnjoj strukturi države, veća će biti očekivanja međunarodnog prava da će država kontrolirati takvog službenika". ${ }^{51}$ Jednako tako i Klaw navodi kako je jedan od oblika ultra vires postupanja, na koje se odnosi čl. 7. Nacrta članaka koji uređuje prekoračenje ovlasti ili postupanje suprotno uputama ${ }^{52}$, i postupanje državnih službenika koji prime mito kako bi nešto napravili ili zaključili neku transakciju, dakle kada npr. "predsjednik, premijer, zakonodavac ili upravni službenik strane države traži ili iznuđuje privatno plaćanje u zamjenu za službeno djelovanje, njegovo se postupanje može jasno pripisati državi". ${ }^{33}$

\subsubsection{Primanje mita u privatnom ili službenom svojstvu}

Države, dakle, ne mogu izbjeći svoju odgovornost tvrdnjama da je tijelo ili osoba o kojoj je riječ počinila nezakonit čin ili da je prekoračila svoje ovlasti. Država će biti stoga odgovorna i ako je neki od "javnih službenika države djelovao na način koji je izričito zabranjen od strane države i kojim je prekršeno međunarodno pravo". ${ }^{54}$ Međutim, treba naglasiti da se i u praksi arbitražnih sudova i u komentarima uz čl. 7. Nacrta članaka radi razlika između djelovanja u okviru službene dužnosti i postupaka koji služe isključivo privatnim ciljevima. ${ }^{55}$

50 Ioannis Kardassopoulos v. The Republic of Georgia, ICSID predmet broj ARB/05/18, Odluka o nadležnosti od 6. 7. 2007., paras. 185 - 194, https://www.italaw.com/sites/ default/files/case-documents/ita0444.pdf (18. rujna 2018.).

51 Crawford; Mertenskötter, op. cit. u bilj. 42, str. 41.

52 Čl. 7. Nacrta članaka glasi: "Djelovanje državnog tijela, osobe ili entiteta koji su ovlašteni izvršavati elemente državne vlasti trebaju se smatrati činima te države po međunarodnom pravu ako tijelo, osoba ili entitet djeluju u tom svojstvu pa čak i ako prekorače svoje ovlasti ili djeluju suprotno uputama."

53 Klaw, op. cit. u bilj. 10, str. 72.

54 Higgins, R., Problems and Process: International Law and How We Use It, Oxford University Press, Oxford, 2004., str. 150.

55 Komentar uz čl. 7., para. 7: "Slučajevi u kojima su službenici djelovali u svojem svojstvu službenika, čak i ako su nezakoniti ili suprotni uputama, moraju se razlikovati od slučajeva u kojima je postupanje toliko izvan okvira njihovih službenih 
Upravo to pitanje, dakle razlikovanje postupanja državnog službenika u isključivo privatnom ili službenom svojstvu, pokazalo se kao ključno u zaključivanju arbitražnih sudova o tome postoji li pripisivost državi. Naime, korupcija logično obuhvaća državne službenike koji koriste svoje javne ovlasti kako bi osigurali neke povlastice investitorima u zamjenu za neku osobnu korist. Postavlja se stoga pitanje postupa li državni službenik koji traži ili primi mito od stranog investitora u službenom svojstvu ili to radi isključivo u privatnom svojstvu.

Arbitražna praksa u pravilu je zauzela stajalište da je kod korupcije riječ o djelovanju u privatnom svojstvu te da stoga nema pripisivosti takvog postupanja državi. Tako je npr. u predmetu World Duty Free protiv Kenije arbitražni sud naglasio kako mito dano predsjedniku Kenije nije bilo u javnu svrhu već da je riječ o "prikrivenom mitu te da stoga njegov primitak ne može zakonski pripisati Keniji. Da je bilo drukčije, to ne bi bilo mito". ${ }^{56}$ Prema Klawu ovakav zaključak o tome da korupcija ne može biti pripisana Keniji "prkosi čl. 4. i čl. 7. Nacrta članaka kojima se propisuje da je postupanje državnih tijela (ovdje je riječ o šefu izvršne vlasti) pripisivo državi čak i kad je ultra vires" ${ }^{57}$ Naime, mito je dano upravo kako bi "utjecalo na službenu odluku predsjednika o davanju koncesije" ${ }^{158}$, stoga po pravilima o odgovornosti države njegovo je postupanje pripisivo Keniji. Utvrđenje arbitražnog suda značilo bi i da država nikada neće odgovarati za korupciju svojih službenika jer je sama narav korupcije da se mito daje u tajnosti, prikriveno, inače ne bi ni bila riječ o korupciji.

Slično je i u predmetu EDF protiv Rumunjske arbitražni sud utvrdio kako "da bi se utvrdila odgovornost države (za korupciju, op. a.), tužitelj mora iznijeti jasne i uvjerljive dokaze ne samo o tome da je zatraženo mito nego i o tome da takav zahtjev (za davanjem mita, op. a.) nije bio stavljen u osobnom interesu osobe koja je tražila mito, nego u ime i za račun tijela rumunjske vlade". ${ }^{59}$ Prema Klawu, ovakvim pristupom arbitražni je sud "ignorirao običajno međunarodno

dužnosti da ga treba poistovjetiti s postupanjem privatnih osoba koje nije pripisivo toj državi."

56 World Duty Free Company v Republic of Kenya, ICSID predmet br. Arb/00/7, pravorijek od 4. 10. 2006., para. 169. https://www.italaw.com/documents/WDFv.KenyaAward. pdf (15. travnja 2018.).

57 Klaw, op. cit. u bilj. 10, str. 93.

58 Kulick, A.; Wendler, C., Corrupt Way to Handle Corruption - Thoughts on the Recent ICSID Case Law on Corruption, Legal Issues of Economic Integration, vol. 37, br. 1, 2010., str. 66.

59 EDF (Services) Limited v. Romania, ICSID Case No. ARB/05/13, pravorijek od 8. 10. 2009., para. 232, https://www.italaw.com/sites/default/files/case-documents/ ita0267.pdf (28. svibnja 2018.). 
pravo o odgovornosti država ..., štoviše, prema takvom stavu, teško je zamislivo da bi država ikada bila odgovorna za mito ili iznudu jer su ova djela, po samoj svojoj prirodi, uvijek počinjena za osobnu korist". ${ }^{60}$

Kao što se vidi iz ovih primjera, pitanje postupa li službenik koji primi mito u isključivo privatnom svojstvu često je odlučujuće kod utvrđivanja postoji li odgovornost države za korupciju. Naravno, i ovdje se postavlja pitanje dvostrukih mjerila i njihove opravdanosti. Naime, ako bi se zauzeo stav da država ne odgovara za koruptivne postupke svojih službenika, jer su poduzeti u njihovu privatnom svojstvu, onda bi se ista logika trebala odnositi i na predstavnike stranih investitora. Zamisliva je tako i situacija u kojoj neki predstavnik investitora da mito javnom službeniku isključivo s ciljem pribavljanja osobne koristi, od čega investitor niti ima koristi niti saznanja. Primjenjujući isti kriteriji, ni investitor ne bi trebao odgovarati za postupanje takvog svojeg zaposlenika.

Također se postavlja pitanje zašto bi motiv državnog službenika uopće bio relevantan. Trebao bi se primjenjivati samo funkcionalni kriterij - dakle, je li primio mito da bi nešto napravio kao privatna osoba ili kao državni službenik. Ako je ovo drugo slučaj, a tako je gotovo uvijek kad su u pitanju strane investicije (naime, investitor nema nikakvog razloga mititi državnog službenika da nešto obavi kao privatna osoba), onda bi se tu trebalo uvijek raditi o postupanju koje je pripisivo državi. Tako Cremades navodi: “ako javni službenik primi mito kako bi obavio svoju javnu dužnost na određeni način, npr. olakšavanjem regulatornih zahtjeva u odnosu na stranu investiciju, onda je postupanje tog službenika pripisivo samoj državi u međunarodnom javnom pravu". ${ }^{61}$ Kako je to Higgins zaključila, "sama činjenica da je službenik utjelovljenje države je dovoljna, i čini bespotrebnim utvrđivati bilo kakvu pogrešku ili namjeru na strani države”. ${ }^{62}$

\subsubsection{Korupcija kao povreda međunarodne obveze države}

Što se tiče drugog elementa za utvrđivanje postoji li odgovornost države, potrebno je utvrditi predstavlja li korupcija povredu međunarodne obveze države, odnosno je li riječ o činu suprotnom međunarodnom pravu. Međunarodne obveze države mogu biti utvrđene bilo međunarodnim običajnim pravom, bilo međunarodnim ugovorima, bilo općim načelima koja su primjenjiva u okviru

60 Klaw, op. cit. u bilj. 10, str. 94.

${ }_{61}$ Cremades, B., Corruption in Investment Arbitration, u: Aksen, G. (ur.), Global Reflection on International Law, Commerce and Dispute Resolution: Liber Amicorum Robert Briner, ICC Publications, Paris, 2005., str. 216.

62 Higgins, op. cit. u bilj. 54, str. 150. 
međunarodnog pravnog poretka. ${ }^{63}$ Pri tome je važno napomenuti da, sukladno čl. 3. Nacrta članak ${ }^{64}$, utvrđivanje predstavlja li korupcija povredu međunarodne obveze države ne zavisi od toga da ona bude protupravna i prema unutrašnjem pravu.

Međunarodna zabrana korupcije ima svoje izvorište još u Bečkoj konvenciji o pravu međunarodnih ugovora iz $1969 .{ }^{65}$, koja u čl. 50. adresira međudržavnu korupciju prilikom zaključenja ugovora. Od tada se međunarodna zabrana korupcije proširila kroz čitav niz međunarodnih ugovora i konvencija kao što su npr. Konvencija Ujedinjenih naroda protiv korupcije ${ }^{66}$, Građanskopravna konvencija Vijeća Europe o korupciji ${ }^{67}$, Kaznenopravna konvencija Vijeća Europe o korupciji ${ }^{68}$, Konvencija OECD-a o borbi protiv podmićivanja stranih dužnosnika u međunarodnim poslovnim transakcijama ${ }^{69}$ itd. koje su se pretvorile u "međunarodno običajno pravo tako da je transnacionalna korupcija nedvojbeno kriminalizirana na međunarodnoj razini".$^{70} \mathrm{Kad}$ se ovome doda Konvencija o rješavanju ulagačkih sporova između država i državljana drugih

63 Klaw, op. cit. u bilj. 10, str. 76.

64 "Utvrđivanje je li neki čin države međunarodno protupravan provodi se po međunarodnom pravu. Na to utvrđenje ne utječe karakterizacija takvog čina kao zakonitog po unutrašnjem pravu."

65 Konvencija je potpisana 23. svibnja 1969., a stupila je na snagu 27. siječnja 1980. Konvencija ima 116 država članica. Republika Hrvatska notificirala je sukcesiju u Konvenciju 15. listopada 1993. god. (Narodne novine, Međunarodni ugovori, br. 12/1993) da bi tekst Konvencije bio objavljen u Narodnim novinama, Međunarodni ugovori, br. 16/1993.

66 Konvenciju je usvojila Opća skupština UN-a 31. listopada 2003., a stupila je na snagu 14. prosinca 2005. Konvencija ima 186 država članica. Republika Hrvatska ratificirala je Konvenciju u veljači 2005. (Narodne novine, Međunarodni ugovori, br. 2/2005).

67 Konvenciju je usvojilo Vijeće Europe 27. siječnja 1999., a stupila je na snagu 1. srpnja 2002. Konvencija ima 35 država članica. Republika Hrvatska ratificirala je Konvenciju u ožujku 2003. (Narodne novine, Međunarodni ugovori, br. 6/2003).

68 Konvenciju je usvojilo Vijeće Europe 4. studenog 1999., a stupila je na snagu 1. studenog 2003. Konvencija ima 35 država članica. Republika Hrvatska ratificirala je Konvenciju u listopadu 2002. (Narodne novine, Međunarodni ugovori, br. $11 / 2002)$.

69 Konvencija je usvojena 17. prosinca 1997., a stupila je na snagu 15. veljače 1999. Konvencija ima 44 države članice. Republika Hrvatska nije pristupila Konvenciji iako je ona otvorena za pristupanje i državama koje nisu članice OECD-a.

70 Wood, T., State Responsibility for the Acts of Corrupt Officials: Applying the 'Reasonable Foreign Investor' Standard, Journal of International Arbitration, vol. 35, br. 1, 2018. , str. 105. 
država ${ }^{71}$ koja u čl. 42. st. $1 .{ }^{72}$ predviđa da arbitražni sudovi prilikom donošenja odluka $\mathrm{u}$ investicijskim sporovima primjenjuju bitna pravila međunarodnog prava, bilo da je ono konvencijsko ili običajno, može se zaključiti da angažiranje države na bilo koji način u korupciji u vezi sa stranim investicijama predstavlja prekršaj njezine međunarodnopravne obveze. Prema Klawu, "zahtijevanje ili iznuda mita od stranog investitora od strane osobe čije je postupanje pripisivo državi ... predstavlja povredu međunarodne obveze države po međunarodnom običajnom pravu" ${ }^{73}$ Ovo potvrđuje i arbitražna praksa, pa je tako arbitražni sud u predmetu EDF protiv Rumunjske utvrdio kako je "traženje mita od strane vladine agencije povreda obveze pravičnog i poštenog tretmana kao i povreda međunarodnog javnog poretka...." ${ }^{74}$

Osim pozivanja na međunarodno običajno pravo, neki autori, kao npr. Llamzon i Sinclair, navode kako se može zaključiti da nadnacionalni javni poredak ${ }^{75}$ "zabranjuje davanje mita i korupciju, barem u kontekstu sporova po investicijskim ugovorima". ${ }^{76}$ Korupcija se također smatra suprotnom međunarodnom javnom poretku, što se temelji na postavci da "nacionalni zakoni, međunarodne konvencije, sudska i arbitražna praksa kao i pravna znanost

${ }^{71}$ Konvencija o rješavanju ulagačkih sporova između država i državljana drugih drŽava stupila je na snagu 14. listopada 1966. i do danas joj je pristupilo 154 država. Konvencijom je uspostavljen Međunarodni centar za rješavanje investicijskih sporova koji predstavlja vodeću svjetsku instituciju za rješavanje investicijskih sporova između država i stranih investitora (ICSID). Do 31. prosinca 2018. registrirano je 706 predmeta pred ICSID-om (izvor: Svjetska banka, The ICSID Caseload - Statistics (Issue 2019-1), dostupno na: https://icsid.worldbank.org/en/Documents/resources/ICSID\%20Web\%20Stats\%202019-1(English).pdf, 17. ožujka 2019.). Republika Hrvatska pristupila je Konvenciji 16. lipnja 1997., a stupila je na snagu u odnosu na RH 22. listopada 1998. (Narodne novine, Međunarodni ugovori, br. 13/1998).

72 "Sud će riješiti spor prema pravnim pravilima o kojima se suglase stranke. Ako se stranke ne suglase o tome, Sud će primijeniti pravo države ugovornice koja je stranka u sporu (kao i njezine propise o sukobu zakona) i one propise međunarodnog prava koji se mogu primijeniti."

73 Klaw, op. cit. u bilj. 10, str. 87.

74 EDF v. Romania, op. cit. u bilj. 59, para. 221.

75 Prema Sikiriću, “izraz 'nadnacionalni javni poredak' (transnational public policy) obuhvaća osnovna načela prirodnog prava, načela univerzalne pravičnosti, ius cogens u međunarodnom javnom pravu i opća načela morala prihvaćena od 'civiliziranih naroda'." (Sikirić, H., Javni poredak kao razlog za poništaj pravorijeka, Zbornik Pravnog fakulteta u Zagrebu, vol. 59, br. 2-3, 2009., str. 228 - 229).

76 Llamzon; Sinclair, op. cit. u bilj. 6, str. 522. 
izražavaju takvu opću osudu (korupcije, op. a.)" ${ }^{77}$ Arbitražni sud u predmetu World Duty Free protiv Kenije izraz "međunarodni javni poredak" interpretira na način da predstavlja "međunarodni konsenzus u odnosu na opće standarde i prihvaćena pravila ponašanja koji se moraju primjenjivati u svim tijelima". ${ }^{78}$ Posebno se to odnosi na korupciju, odnosno situaciju u kojoj je investitor svoju investiciju stekao davanjem mita. Ugovori koji se temelje na korupciji ili koji su zaključeni zbog korupcije ne mogu uživati zaštitu na temelju načela ex turpi causa non oritur actio (iz nepoštenog se ne može tražiti pravna zaštita). ${ }^{79}$

Može se stoga zaključiti kako je pitanje predstavlja li korupcija povredu međunarodne obveze države nesporno kako u pravnoj teoriji, tako i u praksi arbitražnih sudova i to bilo da se u svojim odlukama arbitražni sudovi oslanjaju na međunarodno pravo ili na međunarodni ili nadnacionalni javni poredak. Kako je to naveo Llamzon, "kakve god bile varijacije u sadržaju međunarodnog antikorupcijskog prava, gotovo je nezamislivo da bi neki arbitražni sud dopustio ideju da se međunarodne antikorupcijske norme ne protežu i na zabranu korupcije javnih službenika". ${ }^{80}$

\section{STAJALIŠTA ARBITRAŽNIH SUDOVA U MEĐUNARODNIM INVESTICIJSKIM SPOROVIMA U ODNOSU NA KORUPCIJU}

Korupcija je uvijek bilateralna, odnosno podmićivanje u kontekstu međunarodnih investicija podrazumijeva sudjelovanje i investitora koji daje mito i javnog službenika države primateljice investicije koji prima takvo mito. ${ }^{81}$ Stoga se na korupciju mogu pozivati i investitori koji tvrde da je time država primateljica investicije povrijedila neki od standarda zaštite investitora na koje se obvezala investicijskim ugovorom, a može se pozivati i država primateljica investicije kao "obrana" od investitorovih zahtjeva. Pozivanje na korupciju, dakle, može biti "i mač, kada ga koriste investitori, i štit, kada ga kao prigovor koriste države primateljice investicije" ${ }^{82}$ Od 1987., kada je registriran prvi investicijski spor na

\footnotetext{
Drude, op. cit. u bilj. 12, str. 678.

78 World Duty Free, op. cit. u bilj. 56, para. 139.

79 Ibid.

80 Llamzon, op. cit. u bilj. 1, str. 267.

81 Vidi opširnije u: von Wobeser, C., The Corruption Defense and Preserving the Rule of Law, u: Menaker, A. (ur.), International Arbitration and the Rule of Law: Contribution and Conformity, ICCA Congress Series, vol. 19, Kluwer Law International, Alphen aan den Rijn, 2017., str. $203-224$.

82 Llamzon, op. cit. u bilj. 17, str. 34.
} 
temelju BIU-a ${ }^{83}$, do svibnja 2018., prema javno dostupnim podacima ${ }^{84}$, prigovor korupcije iznesen je u 24 predmeta pred MIA-om ${ }^{85}$, od čega je u tri slučaja prigovor korupcije bio odlučujući za rješavanja predmeta, pri čemu je bitno naglasiti da je u svim slučajevima bila riječ o prigovoru korupcije koji je iznijela država. ${ }^{86}$

Ipak, treba upozoriti na to da se korupcija kao razlog za nepostupanje arbitražnog suda, odnosno uskratu nadležnosti i odbacivanje tužbe, prvi put pojavila u međunarodnoj trgovačkoj arbitraži 1963. u čuvenom pravorijeku suca Lagergrena u ICC predmetu broj $1110 .{ }^{87} \mathrm{U}$ tom predmetu Lagergen je, postupajući sua sponte, dakle iako niti jedna od stranaka u postupku nije iznosila prigovor korupcije, odbio nadležnost arbitražnog suda te je zaključio kako

"ne može biti osporeno da postoje opća načela prava priznata od strane svih civiliziranih naroda prema kojima ugovori kojima se ozbiljno krše boni mores ili međunarodni javni poredak, nisu valjani, ili barem nisu izvršivi te da stoga ne mogu biti prihvaćeni od strane sudova ili arbitara." 88 ... "Stranke koje same sebe uključuju u pothvat kao što je ovaj u pitanju (korupcija, op. a.) moraju prihvatiti da su se time odrekle svakog prava traženja pomoći pravnih mehanizma (bilo nacionalnih sudova ili arbitražnih sudova) u rješavanju njihovih sporova". ${ }^{89}$

83 Asian Agricultural Products Ltd. v. Republic of Sri Lanka, ICSID Case No. ARB/87/3, izvor: UNCTAD Series on International Investment Policies for Development. UN, 2005., dostupno na: https://unctad.org/en/Docs/iteiit20054_en.pdf (17. ožujka 2019.).

84 Predmeti su citirani prema: Alekhin; Shmatenko, op. cit. u bilj. 11, str. 156.

85 Pregled iznesenih navoda, stavova stranaka i arbitražnih sudova kao i ishod prigovora daje detaljno Llamzon, op. cit. u bilj. 1, str. 305 - 320. Vidi i u: Betz, K., Proving Bribery, Fraud and Money Laundering in International Arbitration, Cambridge University Press, Cambridge, 2017., str. 75 - 138.

86 World Duty Free, op. cit. u bilj. 56, Metal-Tech, op. cit. u bilj. 7, Spentex Netherlands, B.V. v. Republic of Uzbekistan, ICSID Case No. ARB/13/26, pravorijek od 27. prosinca 2016.

87 Torres-Fowler, Z., Undermining ICSID: How the Global Antibribery Regime Impairs Investor-State Arbitration, Virginia Journal of International Law, vol. 52, br. 4, 2012., str. 1010.

88 Argentine Engineer v. British Company, ICC Case No. 1110, pravorijek iz 1963., točka 16, https://www.trans-lex.org/201110/_icc-award-no-1110-of-1963-by-gunnar-lagergren-yca-1996-at-47-et-seq-/ (20. lipnja 2018.).

89 Ibid., točka 22. 
Nakon odluke suca Lagergrena u ICC predmetu broj 1110, koja je označila koruptivne ugovore kao suprotne međunarodnom javnom poretku, i zbog toga ništetne odnosno neutužive, ideja da je korupcija nedopustiva po međunarodnom javnom poretku razvila se u važni dio “arbitražne jurisprudencije u kontekstu međunarodnih investicija". ${ }^{90}$

Prvi predmet u kojem su pred MIA-om izneseni navodi o korupciji ${ }^{91}$ bio je SPP protiv Egipta, u kojem je tuženik tvrdio da su tužiteljevi zahtjevi nedopušteni jer se temelje na koruptivnom postupanju tužitelja. ${ }^{92}$ Arbitražni sud navode o korupciji nije ni razmatrao jer nisu iznesene nikakve konkretne tvrdnje o korupciji, nego samo "nespecificirani navodi o nezakonitom postupanju tužitelja..." 93

Od javno dostupnih predmeta u MIA-i jedini predmeti u kojima je prigovor korupcije izravno utjecao na ishod predmeta bili su World Duty Free protiv Kenije iz 2006. godine ${ }^{94}$, Metal-Tech protiv Uzbekistana iz 2013. godine ${ }^{95}$ i Spentex protiv Uzbekistana iz 2016. godine. ${ }^{96}$ Treba istaknuti da se, za razliku od drugih predmeta, World Duty Free protiv Kenije nije temeljio na međunarodnom investicijskom ugovoru, već na trgovačkom ugovoru, međutim, s obzirom na to da ga je rješavao ICSID arbitražni sud, a još više s obzirom na to da su se na njega pozivali drugi arbitražni sudovi koji su postupali na temelju investicijskih ugovora ${ }^{97}$, on se razmatra i u ovom dijelu rada. U ovim predmetima arbitražni sud utvrdio je kako je prigovor korupcije opravdan te je odbacio tužiteljev tužbeni zahtjev, odnosno nije utvrdio postojanje odgovornosti države za mito koje je primio njezin državni službenik, već samo odgovornosti stranog investitora za davanje mita.

Arbitražni sud je u predmetu World Duty Free protiv Kenije iznio svoj negativan stav i o činjenici da je primatelj mita bio kenijski predsjednik na čije se postupanje poziva Kenija iako istodobno nije poduzela ništa kako bi progonila korupciju na koju se sama pozvala u ovom slučaju:

90 Losco, op. cit. u bilj. 5, str. 1217.

91 Kendra, T.; Bonini, A., Dealing with Corruption Allegations in International Investment Arbitration. Reaching a Procedural Consensus?, Journal of International Investment Arbitration, vol. 31, br. 4, 2014., str. 439.

92 Southern Pacific Properties, op. cit. u bilj. 49, para. 127.

93 Ibid., para. 128.

94 World Duty Free, op. cit. u bilj. 56.

95 Metal-Tech, op. cit. u bilj. 7.

96 Spentex Netherlands, B.V. v. Republic of Uzbekistan, ICSID Case No. ARB/13/26, pravorijek od 27. 12. 2016. U vrijeme pisanja ovog članka pravorijek još nije bio javno objavljen, pa se ovdje citira prema Betz, op. cit. u bilj. 85, str. 128 - 136.

97 Npr. Metal-Tech, op. cit. u bilj. 7, para. 292. 
"Bez obzira, kao vrlo uznemirujuća osobina ovog predmeta ostaje to da primatelj tužiteljeva mita nije običan državni službenik, nego najviši državni službenik, predsjednik Kenije, i ta da nakon toga upravo Kenija ističe, kao potpunu obranu od zahtjeva tužitelja, nezakonitosti njezina bivšeg predsjednika. Štoviše, prema dokazima iznesenim pred ovim arbitražnim sudom, davanje mita je očito zahtijevao kenijski predsjednik i nije u cijelosti bilo inicirano od strane tužitelja. Iako je kenijski predsjednik do tada napustio svoju dužnost i po kenijskom Ustavu nema više imunitet od progona, čini se da Kenija nije poduzela ništa kako bi ga procesuirala za korupciju ili kako bi mu oduzela primljeno mito u civilnom postupku. Stoga ne čudi da g. Ali (direktor i većinski vlasnik tužitelja, op. a.) osjeća veliku nepravdu u pravnom postupanju Kenije u ovom predmetu." ${ }^{98}$

Međutim, unatoč ovakvom stavu, arbitražni sud prihvatio je kenijski prigovor korupcije i u cijelosti odbio tužbeni zahtjev navodeći kako "tužbeni zahtjevi koji se temelje na koruptivnom ugovoru ili ugovoru koji je sklopljen na temelju korupcije ne mogu biti podržani od strane arbitražnog suda". ${ }^{99}$ Arbitražni sud, dakle, nije našao elemente da bi se primanje mita od strane predsjednika države pripisalo toj državi, čime je odstupio od načela međunarodnog prava.

U predmetu Metal-Tech protiv Uzbekistana tužitelj je tužio Uzbekistan zbog izvlaštenja, a Uzbekistan je iznio, među ostalim, prigovor korupcije, odnosno da arbitražni sud nema nadležnosti postupati jer je kod poduzimanja investicije tužitelj kršio zakon, odnosno davao mito i to upravo uzbekistanskim državnim službenicima i njima bliskim osobama. Arbitražni sud zaključio je kako je korupcija povezana s poduzimanjem investicije dokazana te kako slijedom toga investicija nije poduzeta sukladno zakonima države primateljice investicije te da stoga ne predstavlja investiciju u smislu relevantnog BIU-a (uzbečko-izraelski ugovor o zaštiti i promicanju investicija) koji sadržava klauzulu zakonitosti. ${ }^{100}$ Budući da se suglasnost Uzbekistana za arbitražu odnosila samo na pravne sporove vezane uz investiciju, nije ispunjen zahtjev iz čl. 25. st. 1. ICSID Konvencije, pa stoga arbitražni sud nije nadležan za postupanje. ${ }^{101}$ Tuženik je, dakle, uspio sa svojim prigovorom korupcije iako je dokazano da su mito primili njegovi službenici i iako nije ništa poduzeo kako bi ih sankcionirao. I u ovom slučaju

\footnotetext{
98 World Duty Free, op. cit. u bilj. 56, para. 180.

99 Ibid., para. 157.

${ }^{100}$ Metal-Tech, op. cit. u bilj. 7, para. 372.

101 Ibid., para. 373.
} 
arbitražni je sud izrazio svoju nelagodu oko ovakvog asimetričnog pristupa u kojem sav rizik korupcije snosi strani investitor:

“Arbitražni sud je svjestan prijepora oko toga da utvrđenje korupcije često teško pogađa tužitelje, dok istodobno možda oslobađa od odgovornosti tuženike koji su možda i sami sudjelovali u korupciji. Točno je da ishodi predmeta u kojima se istakne prigovor korupcije često ne izgledaju zadovoljavajući jer se čini, barem na prvi pogled, da daju nepoštenu prednost tuženiku." ${ }^{102}$

Ipak, za razliku od arbitražnog suda u predmetu World Duty Free protiv Kenije, ovaj arbitražni sud barem je pokušao podijeliti odgovornost, pa je unatoč odbacivanju tužbe odlučio da svaka strana snosi svoje troškove:

“To ipak ne znači (da je država u potpunosti izbjegla odgovornost, op. a.) da država nije sudjelovala u stvaranju situacije koja je dovela do odbacivanja tužbe. S obzirom na ovakvo sudjelovanje koje je implicirano u samoj prirodi korupcije, čini se pravednim da stranke podijele troškove." ${ }^{103}$

Ovakvim zaključkom arbitražni je sud napravio mali pomak prema uklanjanju asimetrije. Naime, iako nije raspravljao o odgovornosti države, odnosno o pripisivosti postupanja državnih službenika koji su primili mito, ipak je kroz odluku o trošku izričito naveo da je država sudjelovala u korupciji. Postavlja se pitanje kako je to država mogla sudjelovati u korupciji, a ne biti za nju odgovorna.

U predmetu Spentex protiv Uzbekistana ${ }^{104}$ tužitelj je potraživao naknadu štete od tuženika zbog povreda standarda zaštite koji mu je bio zajamčen, među ostalim, i po bilateralnom ugovoru o zaštiti investicija između Uzbekistana i Nizozemske. Tuženik je, s druge strane, istaknuo prigovor korupcije tvrdeći da je tužitelj poduzeo investiciju zahvaljujući davanju mita državnim službenicima Uzbekistana. Arbitražni sud utvrdio je kako je poduzimanje investicije "očito uključivalo koruptivne aktivnosti na strani investitora i na strani tuženikovih službenika". ${ }^{105}$ Arbitražni je sud tuženikov prigovor korupcije, odnosno zahtjev za odbacivanjem tužbe zbog korupcije uz istodobno odbijanje imenovanja navodno korumpiranih službenika, označio kao

102 Ibid., para. 389.

103 Ibid., para. 422.

104 U vrijeme pisanja ovog članka pravorijek još nije bio javno objavljen, pa se ovdje citira prema Betz, op. cit. u bilj. 85, str. 128 - 136.

105 Spentex, op. cit. u bilj. 96, para. 934. 
“pristup koji bi osnažio perverzne poticaje za tužene države u kontekstu korupcije. Njime bi se tražilo od investicijskog arbitražnog suda da odbaci tužiteljev zahtjev istodobno dajući imunitet tuženoj državi i u odnosu na navodnu korupciju i u odnosu na tužiteljev investicijski tužbeni zahtjev."106

Međutim, bez obzira na to, arbitražni sud odbacio je tuženikovu tužbu kao nedopuštenu i to upravo zbog toga što je korupcija suprotna "temeljnim vrijednostima međunarodnog javnog poretka". ${ }^{107}$

Ipak, to je prvi slučaj da je arbitražni sud razmatrao detaljnije problem korupcije i činjenicu da je kod korupcije uvijek potrebno dvoje - i onaj koji daje mito i onaj koji prima mito - te zaključio da su "ako prigovor korupcije rezultira uvijek odbacivanjem tužbe, korumpirani investitori kažnjeni za svoje postupanje, dok istodobno korumpirane države nisu". ${ }^{108}$ Arbitražni sud je dalje utvrdio da prema postojećem pravnom uređenju nema mogućnosti sankcionirati korumpiranu državu primateljicu investicije, međutim, pokušao je pronaći rješenje u okviru odluke o troškovima, pa je naložio svakoj strani da snosi svoje troškove. Osim toga, naložio je tuženiku da uplati 8 milijuna dolara u Svjetsku antikorupcijsku inicijativu Programa Ujedinjenih naroda za razvoj 2014. - 2017. (engl. UNDP Global Anti-corruption Initiative (GAIN) 2014-2017) ${ }^{109}$, a ako to ne napravi, snosit će sve troškove postupka uključujući i tri četvrtine tužiteljevih odvjetničkih troškova. ${ }^{110}$

Prema sadašnjem stanju prakse, arbitražni sudovi u investicijskim sporovima su se prigovorom korupcije bavili kao pitanjem nadležnosti pa su, kad su utvrdili da je postojala korupcija u fazi nastanka investicije, odbijali nadležnost, odbacivali tužbe i time uskraćivali pružiti zaštitu investitoru. Time su ovo pitanje rješavali binarno - sve ili ništa - što je u pravilu išlo na štetu samo investitoru.

${ }_{106}$ Ibid., para. 940.
${ }_{107}$ Ibid., para. 944.
108 Ibid., para. 973.

109 Program UNDP-a čiji je cilj, na temelju sredstava prikupljenih od donatora, jačati sustave, institucije i inicijative građanskog društva kako bi se poboljšalo upravljanje i pružanje javnih usluga te kako bi se kroz to dala podrška implementaciji UNCAC-a i jačanju antikorupcijskih tijela. O tome više na: https://www.undp.org/ content/dam/undp/library/Democratic\%20Governance/Anti-corruption/globalanticorruption_final_web2.pdf (17. ožujka 2019.).

110 Spentex, op. cit. u bilj. 96, para 981. 


\section{POKUŠAJI ARBITRAŽNIH SUDOVA U IZBJEGAVANJU ASIMETRIJE KOD ODGOVORNOSTI ZA KORUPCIJU}

Arbitražni sudovi nisu do kraja bili zadovoljni svojim binarnim odlukama i otklanjanjem odgovornosti države, pa su u okviru postojećeg režima pokušavali barem naznačiti da, iako posljedice snosi strani investitor, postoji i neka vrsta odgovornosti država. U praksi su se kristalizirali sljedeći pristupi: prozivanje države ili nekog njezina službenika za umiješanost u korupciju (4.1.), odbijanje prigovora korupcije ako se ne procesuira korupcija (4.2.), "kažnjavanje” države kroz odluku o trošku postupka (4.3.) i nalaganje isplate naknade koja bi hipotetski pripala tužitelju nekom međunarodnom antikorupcijskom tijelu (4.4.). Kao što je vidljivo iz navedenih primjera, arbitražna praksa pokušala je u okviru postojećih okvira naći rješenja kojima bi se izbjegla asimetrija kod prigovora korupcije i državu, barem dijelom, učinila odgovornom za korupciju u kojoj sudjeluju njezini službenici.

\subsection{Prozivanje države ili nekog njezina službenika za umiješanost u korupciju}

Tako su postupili arbitražni sudovi u predmetima World Duty Free protiv Kenije: "Bez obzira, kao vrlo uznemirujuća osobina ovog predmeta ostaje to da primatelj tužiteljeva mita nije obični državni službenik, nego najviši državni službenik, predsjednik Kenije i ta da nakon toga upravo Kenija ističe, kao potpunu obranu od zahtjeva tužitelja, nezakonitosti njezina bivšeg predsjednika". ${ }^{111}$ Jednako i Spentex protiv Uzbekistana, u kojem je arbitražni sud utvrdio kako je poduzimanje investicije "očito uključivalo koruptivne aktivnosti na strani investitora i na strani tuženikovih službenika”. ${ }^{112}$

Ovakva osuda nema "opipljivu” vrijednost, međutim, s obzirom na to da su postupci pred MIA-om sve javniji, to može imati određene učinke kako u odnosu na domaću javnost, tako i u odnosu na potencijalne strane investitore.

\subsection{Odbijanje prigovora korupcije ako se ne procesuira korupcija}

Do sada takav primjer nije zabilježen iako je razmatran u predmetu Wena protiv Egipta: "Uzimajući u obzir činjenicu da je egipatska vlada bila upoznata sa sporazumom od strane g. Sultana, ali je odlučila (zbog kojeg god razloga) ne

111 World Duty Free, op. cit. u bilj. 56, para. 180.

112 Spentex, op. cit. u bilj. 96, para. 934. 
procesuirati g. Kandila, arbitražni sud nije sklon dati imunitet Egiptu od odgovornosti u ovom arbitražnom postupku i to zato što sad tvrdi da je ugovor $\mathrm{s} g$. Kandilom bio nezakonit po egipatskom pravu". ${ }^{13}$ Arbitražni sud na kraju ipak nije prihvatio prigovor korupcije jer Egipat nije dokazao njezino postojanje. ${ }^{114}$

\section{3. "Kažnjavanje" države kroz odluku o trošku postupka}

Upotrebljavajući široke ovlasti koje imaju kod odluke o trošku, npr. čl. 61. st. 2. ICSID Konvencije ${ }^{115}$, arbitražni sudovi u predmetu Metal-Tech protiv Uzbekistana $^{116}$ i Spentex protiv Uzbekistana ${ }^{117}$ naložili su tuženim državama da, iako su uspjele s prigovorom korupcije, snose svoje troškove.

\subsection{Nalaganje isplate naknade koja bi hipotetski pripala tužitelju nekom međunarodnom antikorupcijskom tijelu}

U predmetu Spentex protiv Uzbekistana arbitražni je sud primijenio "revolucionarnu" metodu na način da je odredio da tuženik uplati 8 milijuna dolara u Svjetsku antikorupcijsku inicijativu UNDP-a, a ako to ne napravi, snosit će sve troškove postupka, uključujući i tri četvrtine tužiteljevih odvjetničkih troškova. ${ }^{118}$

\section{MOGUĆA RJEŠENJA KAKO BI SE SPRIJEČILA ASIMETRIJA U ODGOVORNOSTI}

Kod mogućih rješenja kojima bi se mogla izbjeći asimetrija u odgovornosti između investitora i države domaćina kod slučajeva primanja mita od strane

${ }_{113}$ Wena Hotels Ltd. v. Arab Republic of Egypt, ICSID Case No. ARB/98/4, pravorijek od 8. 12. 2000., para. 116, https://www.italaw.com/sites/default/files/case-documents/ ita0902.pdf (1. lipnja 2018).

114 Ibid., para. 117.

115 "U slučaju arbitražnog postupka Sud će, ako se stranke drukčije ne dogovore, procijeniti troškove koje su stranke imale u svezi s postupkom i odlučit će kako i tko će platiti troškove, nagrade i izdatke članova Suda i naknade za korištenje olakšica Centra."

116 Metal-Tech, op. cit. u bilj. 7, para. 422.

117 Spentex, op. cit. u bilj. 96, para. 980.

118 Ibid., para. 981. 
službenika te države treba razlikovati ona koja se tiču promjene zakonodavnog okvira, dakle, izmjenama relevantnih investicijskih ugovora i ona koja bi se mogla primjenjivati i bez izmjene ugovora, korištenjem već postojećih mehanizma. Cilj ovih prijedloga rješenja je postizanje ravnoteže u odgovornosti za korupciju i izbjegavanje situacija u kojima država koja bi, prema pravilima međunarodnog prava, trebala odgovarati za korupciju svojih službenika, isticanjem prigovora korupcije izbjegava odgovornost i sve posljedice korupcije prebacuje na investitora.

\subsection{Izmjena investicijskih ugovora}

Ovakav pristup čini se pravno najkorektniji, međutim, postavlja se pitanje koliko je politički ostvariv, odnosno jesu li države spremne odreći se mogućeg prigovora korupcije koji, prema dosadašnjoj praksi, ide isključivo njima u prilog. Ako bi se išlo na izmjenu investicijskih ugovora, mogla bi se uvrstiti odredba, slična onoj kakvu je predložio arbitražni sud u predmetu Spentex protiv Uzbekistana, prema kojoj bi

"Arbitražni sud trebao moći raspraviti tužbeni zahtjev kao da nije bilo korupcije i, u slučaju da utvrdi da je država odgovorna, izračunati naknadu štete na koju bi tužitelj imao pravo da nije poduzeo investiciju služeći se korupcijom i onda naložiti da taj iznos bude plaćen ne tužitelju nego odgovarajućem tijelu UN-a ili OECD-a ili nekog drugog tijela koje se bori protiv korupcije."119

U slučaju uspješnog prigovora korupcije, dakle, ako se dokaže da je investicija poduzeta korupcijom u kojoj su bili uključeni i strani investitor kao davatelj i državni službenici kao primatelji mita (prvi korak), arbitražni bi sud bio ovlašten utvrditi je li država prekršila obveze iz investicijskog ugovora (drugi korak) i, ako utvrdi da jest, utvrditi iznos naknade koji bi pripao investitoru da nije bilo prigovora korupcije (treći korak). Nakon toga arbitražni sud odredio bi da država primateljica investicije tako utvrđen iznos treba uplatiti nekoj međunarodnoj organizaciji koja se bori protiv korupcije (četvrti korak). Ovdje je važno naglasiti i da, kako navodi Drude, "nije suprotno nadnacionalnom javnom poretku održati ugovor kod čijeg je nastanka bilo korupcije niti usvojiti zahtjev za povratom (uloženog, op. a.) investitoru (kad i usvoji prigovor korupcije koji istakne država, op. a.)". ${ }^{120}$

119 Ibid., para. 978.

120 Drude, op. cit. u bilj. 12, str. 705. 
Druga je mogućnost da se u investicijskim ugovorima izričito predvidi da država odgovara za korupciju svojih službenika ako je bila riječ o poduzimanju službene radnje bez obzira na motive zbog kojih je državni službenik primio ili zahtijevao mito te da je riječ o pitanju merituma, a ne nadležnosti. Arbitražni sud bi, dakle, bez obzira na prigovor korupcije bio nadležan za rješavanje o meritumu u okviru kojeg bi riješio i pitanje korupcije.

\subsection{Primjena pravila međunarodnog prava - prešutno prihvaćanje}

Čini se da i u sadašnjem režimu MIP-a postoje instrumenti koji bi arbitražnim sudovima omogućili izbjegavanje asimetrije u odgovornosti kod korupcije - primjenom instituta prešutnog prihvaćanja - acquiescence.

Razdoblje pasivnosti u kojem država, nakon saznanja o postojanju korupcije prilikom stjecanja investicije, ništa ne poduzima s tim u vezi, moglo bi predstavljati temelj za uskraćivanje mogućnosti uspješnog isticanja prigovora korupcije državi primateljici investicije. Naime, prema čl. 45(b) Nacrta članaka ${ }^{121}$, jedan od razloga za gubitak prava države na prigovor odgovornosti je i ako se može smatrati da je "oštećena država na temelju svojeg postupanja valjano pristala na gubitak prava na tužbu". ${ }^{122}$ Naravno, to se načelo može primijeniti pod uvjetom da je u okolnostima slučaja bilo razumno očekivati da će država poduzeti odgovarajuću akciju. U praksi bi to značilo da postupanje države koje se može smatrati prihvaćanjem može dovesti arbitražni sud do "zaključka da se prigovor korupcije države primateljice treba smatrati napuštenim”. ${ }^{123}$ To bi se moglo odnositi na situacije u kojima država primateljice investicije, koja je upoznata sa slučajevima korupcije, ništa ne poduzima kako bi provela učinkovitu istragu i kazneno progonila počinitelje, osobito one koji su njezini službenici. Primjenu instituta prešutnog prihvaćanja treba promatrati ne samo u svjetlu konkretnog predmeta i neprocesuiranja korupcije već i u svjetlu opće politike države prema korupciji. Naime, nečinjenje je istovrijedan temelj za odgovornost države kao

121 Što se tiče drugog razloga iz navedenog članka, odricanja (waiver), on se ne obrađuje ovdje jer je pretpostavka za odricanje da nadležno tijelo države da odgovarajuću izjavu što odricanje čini "neupotrebljivim” u praksi korupcije u međunarodnim investicijama jer je teško zamislivo da bi bilo koja država javno izjavila da se odriče svojih prava koja proizlaze iz činjenice da je investitor počinio neko koruptivno djelo.

122 Čl. 45. Nacrta članaka glasi: "Ne može se pozivati na odgovornost države ako: (a) se valjano odrekla tužbe; (b) je oštećena država na temelju svojeg postupanja valjano pristala na gubitak prava na tužbu."

123 Llamzon, op. cit. u bilj. 1, str. 272. 
i činjenje. Propust u procesuiranju korupcije može istodobno predstavljati i "povredu materijalnog nacionalnog i međunarodnog prava kao i oblik odricanja po pravu o odgovornosti država". ${ }^{124}$

Stoga, kad god država istakne prigovor korupcije, da bi on bio prihvaćen, država bi morala dokazati da je poduzimala mjere radi otkrivanja, sprečavanja i procesuiranja korupcije. Ako je država svjesna da je investitor prilikom poduzimanja investicije djelovao koruptivno, pa na to ne odgovori pravnim mehanizmima koji joj stoje na raspolaganju, ne bi trebala moći s uspjehom isticati prigovor korupcije. Kao je to naveo Raouf: "Ako država domaćin ne poduzme ništa kako bi istražila ili kaznila koruptivna djela svojih službenika, ona time gubi pravo pozivati se na korupciju kao obranu (od zahtjeva investitora zbog povrede njegovih prava, op. a.)". ${ }^{125}$

Država se ne bi mogla pozivati da nije znala za korupciju pa da zato nije ništa poduzela kako bi se procesuirali odgovorni. S jedne strane, uvijek je nužno riječ o korupciji na strani javnih službenika za koje odgovara država, iz čega proizlazi presumpcija da država zna što oni rade, a ako to stvarno i nije znala, to ide na njezinu štetu i ne bi se trebala moći pozivati na neznanje. Usporedbe radi, ako neki državni službenik primi mito od investitorova konkurenta pa zbog toga oduzme investitoru npr. koncesiju, država će odgovarati za takvo postupanje svojeg službenika iako za njega nije znala.

S druge strane, što se čini još važnijim, država za takvu korupciju ima saznanja barem od trenutka kada je odlučila staviti prigovor korupcije. Dakle, ako država ima dovoljno saznanja da može staviti prigovor korupcije, koji mora nužno i obrazložiti i predati odgovarajuće dokaze, logično je da ima dovoljno saznanja i za pokretanje istrage do trenutka kada arbitražni sud odlučuje o prigovoru korupcije. Ako država tvrdi da nema dovoljno elemenata za pokretanje istrage, onda ni njezin prigovor korupcije nužno nema dovoljno elemenata da bi bio prihvaćen. Kod kršenja neke međunarodne obveze država, ako već ne može spriječiti takvo kršenje, treba barem poduzeti sve što je u njezinoj moći kako bi procesuirala počinitelje i sanirala povredu.

Kako je to naveo Llamzon:

“Postoji potencijalni moralni rizik u omogućavanju državama primateljicama investicija da se, na temelju prošle korupcije, izoliraju od inače legitimnih obveza prema investitorima. Čini se jedino pravično kako bi se za prihvaćanje

124 Ibid., str. 275.

125 Raouf, M. A., How Should International Arbitrators Tackle Corruption Issues, ICSID Review - Foreign Investment Law Journal, vol. 24, br. 1, 2009., str. 135. 
prigovora korupcije kao potpune obrane (država primateljica investicija, op. a.) trebalo tražiti od država da dokažu da su aktivno pokušavale progoniti korumpirane javne službenike i vratiti primljeno mito, u suprotnom se može zaključiti da postoji nedostatak stvarnog interesa u borbi protiv korupcije i time učiniti vjerodostojnim prigovor estoppela (autor u tekstu izjednačava estoppel s prešutnim prihvaćanjem, op. a.)."126

Takvim pristupom arbitražni sudovi bi mogli izbjeći “zamku” odlučivanja o prigovoru korupcije u fazi odlučivanja o nadležnosti i o njemu odlučivati u fazi odluke o meritumu te bi mogli kod svoje odluke uzeti u obzir doprinos i jedne i druge strane korupciji, utjecaju koje je imala na samu investiciju (npr. je li riječ o slučaju kada je mito dano za dobivanje neke dozvole koju bi investitor i inače dobio, rangu državnih službenika koji su primili mito i sl.) te sve to staviti u kontekst odluke o meritumu glavne stvari, odnosno zahtjeva investitora za zaštitom njegovih prava.

\section{ZAKLJUČAK}

Međunarodno pravo jasno postavlja kriterije za odgovornost države za postupanje njezinih službenika i oni se kao takvi primjenjuju i u MIP-u. Međutim, kada je riječ o slučajevima u kojima država istakne prigovor korupcije kao obranu od zahtjeva investitora, arbitražna praksa je drukčija i ne primjenjuje te kriterije, i to u pravilu s obrazloženjem da je riječ o postupanju državnih službenika koje je poduzeto isključivo u njihovom privatnom interesu, pa da država za to ne odgovara. Takav pristup znači da se uvijek "kažnjava" samo jedna strana u korupciji iako su kod korupcije nužno potrebne dvije strane - i davatelj i primatelj mita. Također, umjesto suzbijanja korupcije, državama se na taj način daje neka vrsta "poticaja" za sudjelovanje u nesprečavanju korupcije ili nesprečavanje korupcije. Naime, države će zapravo profitirati jer ako država primateljica investicije "povrijedi investiciju stranog investitora koji je dao mito kako bi sklopio određeni ugovor s takvom državom, uspješna obrana korupcijom će u potpunosti otkloniti odgovornost države ... npr. kod izvlaštenja, država može izaći s pozitivnom pozicijom unatoč činjenici da je bila bitno umiješana u nezakonito plaćanje dok investitor gubi u cijelosti svoju investiciju”. ${ }^{127}$

${ }^{126}$ Llamzon, A., The Control of Corruption Through International Investment Arbitration: Potential and Limitation, Proceedings of the Annual Meeting (American Society of International Law), vol. 102, 2008., str. 210.

127 Torres-Fowler, op. cit. u bilj. 87, str. 999. 
Arbitražni sudovi svjesni su nedostataka u dosadašnjem pristupu prigovoru korupcije koji je binaran i, ako uspije, državu u potpunosti oslobađa odgovornosti, npr. za izvlaštenje, te svu odgovornost i štetu prebacuje na investitora. Stoga sve više pokušavaju pronaći rješenje za ovaj problem i to u pravilu kroz odluku o trošku. Dakle, i kad odbacuju tužbeni zahtjev, odlučuju da će stranke podijeliti trošak. Takva rješenja, međutim, nisu zadovoljavajuća te bi se arbitražni sudovi morali početi služiti mehanizmom iz međunarodnog prava koji im i sada stoji na raspolaganju - načelom prešutnog prihvaćanja. Prema tome bi država koja zna za korupciju prilikom poduzimanja investicije i nastavlja postupati kao da takve korupcije nema (npr. ubire koncesijsku naknadu) ili ne poduzima nikakve radnje kako bi se počinitelji sankcionirali, trebala biti spriječena u uspješnom isticanju prigovora korupcije. Osim toga, bilo bi dobro kada bi države, kao poticaj borbi protiv korupcije, prilikom sklapanja BIU-a ugovarale takve odredbe kojima se jasno propisuje odgovornost države za koruptivna djela svojih službenika uz istodobnu obvezu progona takvih počinitelja te koji takvo postupanje čini preduvjetom za pozivanje države na koruptivno djelo investitora. Ovakvim pristupom izbjegla bi se postojeća asimetrija u pristupu odgovornosti države i investitora te bi se i u ovom segmentu MIP i arbitražna praksa uskladili s načelima međunarodnog javnog prava koja uređuju odgovornost država. Također, ovo bi bio izravan poticaj u borbi protiv korupcije u međunarodnim investicijama. Naime, države bi morale aktivno raditi ne samo na sprečavanju nego i na procesuiranju korupcije jer u protivnom ne bi mogle uspjeti sa svojim prigovorima korupcije.

\section{LITERATURA}

\section{Knjige i časopisi}

Alekhin, S.; Shmatenko, L., Corruption in Investor-State Arbitration - It Takes Two to Tango, u: Asoskov A. V. et al. (ur), New Horizons of International Arbitration, Issue 4: Collection of Articles, Association of Private International and Comparative Law Studies, Moskva, 2018., str. 150-179.

Alvarez, J. E., Are Corporations Subjects of International Law, Santa Clara Journal of International Law, vol. 9, br. 1, 2011., str. 1-35.

Betz, K. Proving Bribery, Fraud and Money Laundering in International Arbitration, Cambridge University Press, Cambridge, 2017.

Braun, T. R., Globalization-Driven Innovation: The Investor as a Partial Subject in Public International Law; An Inquiry into the Nature and Limits of Investor Rights, Journal of World Investment and Trade, br. 15, 2014., str. 73-116, https:/doi. org/10.1163/22129000-01502003 
Bungenberg, M.; Griebel, J.; Hobe, S.; Reinisch, A., General Introduction to International Investment Law, u: Bungenberg, M. et al. (ur.), International Investment Law, Nomos, Baden-Baden, 2015., str. 1-6.

Crawford, J., Investment Arbitration and ILC Articles on State Responsibility, ICSID Review - Foreign Investment Law Journal, vol. 25, br. 1, 2010., str. 127-199, https://doi.org/10.1093/icsidreview/25.1.127

Crawford, J., The ILC's Articles on Responsibility of States for Internationally Wrongful Acts: A Retrospect, The American Journal of International Law, vol. 96, br. 4, 2002., str. 874-890, https://doi.org/10.2307/3070683

Crawford, R. J.; Mertenskötter, P., The Use of the ILC's Attribution Rules in Investment Arbitration, u: Kinnear, M. et al. (ur.), Building International Investment Law: The First 50 Years of ICSID, Kluwer Law International, Alphen aan den Rijn, 2015., str. 27-42.

Crawford, J.; Olleson, S., The Application of the Rules of State Responsibility, u: Bungenberg, M. et al. (ur.), International Investment Law, Nomos, Baden-Baden, 2015., str. 411-441.

Cremades, B., Corruption in Investment Arbitration, u: Aksen, G. (ur.), Global Reflection on International Law, Commerce and Dispute Resolution: Liber Amicorum Robert Briner, ICC Publications, Paris, 2005., str. 203-220.

Dolzer, R.; Schreuer, C., Principles of International Investment Law, 2nd ed., Oxford University Press, Oxford, 2012.

Drude, J., Fiat iustitia, ne pereat mundus: A Novel Approach to Corruption and Investment Arbitration, Journal of International Arbitration, vol. 35, br. 6, 2018. str. 665-718.

Higgins, R., Problems and Process: International Law and How We Use It, Oxford University Press, Oxford, 2004.

Hobér, K., State Responsibility and Investment Arbitration, Journal of International Arbitration, vol. 25, br. 5, 2008., str. 545-568.

Hofmann, R., The Protection of Individuals under Public International Law, u: Bungenberg, M. et al. (ur.), International Investment Law, Nomos, Baden-Baden, 2015., str. 46-64.

Kendra, T.; Bonini, A., Dealing with Corruption Allegations in International Investment Arbitration. Reaching a Procedural Consensus?, Journal of International Investment Arbitration, vol. 31, br. 4, 2014., str. 439-454.

Klaw, W., B., State Responsibility for Bribe Solicitation and Extortion: Obligations, Obstacles and Opportunities, Berkeley Journal of International Law, vol. 33, br. 1, 2015., str. 60-113, https://doi.org/10.15779/Z38HV9D 
Kulick, A.; Wendler, C., Corrupt Way to Handle Corruption - Thoughts on the Recent ICSID Case Law on Corruption, Legal Issues of Economic Integration, vol. 37, br. 1, 2010, str. 61-86.

Llamzon, A., Corruption in International Investment Arbitration, Oxford University Press, Oxford, 2014.

Llamzon, A., On Corruption's Peremptory Treatment in International Arbitration, u: Baizeau, D.; Kreindler, R. (ur.), Addresing Issues of Corruption in Commercial and Investment Arbitration, Dossiers of the ICC Institute of World Business law, vol. 13, Kluwer Law International, Alphen aan den Rijn, 2015., str. 32-50.

Llamzon, A., The Control of Corruption Through International Investment Arbitration: Potential and Limitation, Proceedings of the Annual Meeting (American Society of International Law), vol. 102, 2008., str. 208-212.

Llamzon, A.; Sinclair, C. A., Investor Wrongdoing in Investment Arbitration: Standards Governing Issues of Corruption, Fraud, Misrepresentation and Other Investor Misconduct, u: van den Berg, A. J. (ur.), Legitimacy: Myths, Realities, Challenges, ICCA Congress Series, vol. 18, Kluwer Law International, Alphen aan den Rijn, 2015., str. 451-530.

Losco, A. M., Streamlining the Corruption Defense: A Proposed Framework for FCPA-ICSID Interaction, Duke Law Journal, vol. 63, br. 5, 2014., str. 1201-1242.

Raouf, M. A., How Should International Arbitrators Tackle Corruption Issues, ICSID Review - Foreign Investment Law Journal, vol. 24, br. 1, 2009., str. 116-136, https://doi.org/10.1093/icsidreview/24.1.116

Salacuse, J. W., The Law of Investment Treaties, Oxford University Press, Oxford, 2015.

Seršić, M., Diplomatska zaštita, Zbornik Pravnog fakulteta u Zagrebu, vol. 62, br. 1-2, 2012., str. 735-751.

Seršić, M., Međunarodnopravna odgovornost država: pitanje krivnje i dužne pažnje, Zbornik Pravnog fakulteta u Zagrebu, vol. 49, br. 1, 1999., str. 5-22.

Sikirić, H., Javni poredak kao razlog za poništaj pravorijeka, Zbornik Pravnog fakulteta u Zagrebu, vol. 59, br. 2-3, 2009., str. 225-268.

Spiermann, O., Individual Rights, State Interests and the Power to waive ICSID Jurisdiction under Bilateral Investment Treaties, Arbitration International, vol. 20, br. 2, 2004., str. 179-212, https://doi.org/10.1093/arbitration/20.2.179

Spiermann, O., Twentieth Century Internationalism in Law, European Journal of International Law, vol. 18, br. 5, 2007., str. 785-814, https://doi.org/10.1093/ ejil/chm045 
Torres-Fowler, Z., Undermining ICSID: How the Global Antibribery Regime Impairs Investor-State Arbitration, Virginia Journal of International Law, vol. 52, br. 4, 2012., str. 996-1031.

Von Wobeser, C., The Corruption Defense and Preserving the Rule of Law, u: Menaker, A. (ur.), International Arbitration and the Rule of Law: Contribution and Conformity, ICCA Congress Series, vol. 19, Kluwer Law International, Alphen aan den Rijn, 2017., str. 203-224.

Wittich, S., State Responsibility, u: Bungenberg, M. et al. (ur.), International Investment Law, Nomos, Baden-Baden, 2015, str. 23-45.

Wittich, S., The International Law Commission's Articles on the Responsibility of States for Internationally Wrongful Acts Adopted on Second Reading, Leiden Journal of International Law, vol. 15, br. 4, 2002., str. 891-920, https://doi.org/10.1017/ S0922156502000390

Wood, T., State Responsibility for the Acts of Corrupt Officials: Applying the 'Reasonable Foreign Investor' Standard, Journal of International Arbitration, vol. 35, br. 1, 2018., str. 103-118.

Yearbook of the International Law Commission 2001, sv. 2, dio 2, United Nations, New York, Geneva, 2007.

\section{Arbitražne i sudske odluke}

Argentine Engineer v. British Company, ICC Case No. 1110, Pravorijek iz 1963, točka 16, https://www.trans-lex.org/201110/_icc-award-no-1110-of-1963-bygunnar-lagergren-yca-1996-at-47-et-seq-/ (20.6.2018).

EDF (Services) Limited v. Romania, ICSID Case No. ARB/05/13, Pravorijek od 8.10.2009, para. 221,https://www.italaw.com/sites/default/files/case-documents/ita0267.pdf (28.5.2018).

Elie George Siag and Clorinda Vecchi v. The Arab Republic of Egypt, ICSID Case No. ARB/05/15, Pravorijek od 1.6.2009, https://www.italaw.com/sites/default/ files/case-documents/ita0786_0.pdf (1.6.2018).

German Settlers in Poland, Advisory Opinion, 1923, PCIJ Ser.B., No6, p. 22, https:// www.italaw.com/sites/default/files/case-documents/ita0726.pdfwww.icj-cij. org/files/permanent-court-of-international-justice/serie_B/B_06/Colons_allemands_en_Pologne_Avis_consultatif.pdf (15.9.2018).

Ioannis Kardassopoulos v. The Republic of Georgia, ICSID predmet broj ARB/05/18, Odluka o nadležnosti od 6.7.2007, https:/www.italaw.com/sites/default/files/ case-documents/ita0444.pdf (18.9.2018). 
Jan de Nul NV and Dredging International NV v.Arab Republic of Egypt, Case No. ARB/04/13, Decision on jurisdiction, 16 6. 2006, https://www.italaw.com/ sites/default/files/case-documents/ita0439.pdf (10.9.2018).

Mavrommatis Palestine Concessions (Greece v. United Kingdom), PCIJ Reports, Series A, br. 2, str. 12.

Metal-Tech Ltd. v. Republic of Uzbekistan, ICSID Case No. ARB/10/3, Pravorijek od 4.10.2013., para. 422, https://www.italaw.com/sites/default/files/case-documents/italaw3012.pdf (1.6.2018).

SGS Société Générale de Surveillance S.A. v. Republic of the Philippines, ICSID Case No. ARB/02/6, Odluka o prigovorima na nadležnost od 29.1.2004, https:// www.italaw.com/sites/default/files/case-documents/ita0782.pdf, 19.3.2019.

Southern Pacific Properties (Middle East) Limited v. The Arab Republic of Egypt, ICSID predmet broj ARB/84/3, Pravorijek od 20.5.1992, https://www.italaw.com/ sites/default/files/case-documents/italaw6314_0.pdf (17.9.2018).

Spentex Netherlands, B.V. v. Republic of Uzbekistan, ICSID Case No. ARB/13/26, Pravorijek od 27.12. 2016. citirano prema: Betz, K. Proving Bribery, Fraud and Money Laundering in International Arbitration, Cambridge University Press, 2017.

United States Diplomatic and Consular Staff in Tehran (USA v. Iran), Judgment, I.C.J. Reports 1980, para. 56 https://www.icj-cij.org/files/case-related/64/06419800524-JUD-01-00-EN.pdf (1.7.2018).

Wena Hotels Ltd. v. Arab Republic of Egypt, ICSID Case No. ARB/98/4, Pravorijek od 8.12.2000, https://www.italaw.com/sites/default/files/case-documents/ ita0902.pdf (1.6.2018).

World Duty Free Company v Republic of Kenya, ICSID predmet br. Arb/00/7, Pravorijek od 4.10.2006, https://www.italaw.com/documents/WDFv.KenyaAward. pdf (15.4.2018).

\section{Mrežni izvori}

Nacrt Članka o odgovornosti država za međunarodno protupravne čine iz 2001. god., http://legal.un.org/ilc/texts/instruments/english/commentaries/9_6_2001.pdf (1.6.2018).

OECD Convention on Combating Bribery of Foreign Public Officials in International Business Transactions, http://www.oecd.org/corruption/oecdantibriberyconvention.htm (1.6.2018).

UNCTAD Series on International Investment Policies for Development, UN 2005, dostupno na: https://unctad.org/en/Docs/iteiit20054_en.pdf, 17.3.2019. 


\section{Pravni akti}

Bečka konvenciji o pravu međunarodnih ugovora, Narodne novine, Međunarodni ugovori, br. 16/1993.

Građanskopravna konvencija Vijeća Europe o korupciji, Narodne novine, Međunarodni ugovori, br. 6/2003.

Kaznenopravna konvencija Vijeća Europe o korupciji, Narodne novine, Međunarodni ugovori, br. 11/2000.

Konvencija o rješavanju ulagačkih sporova između država i državljana drugih država, Narodne novine, Međunarodni ugovori, br. 2/1998.

Konvencija Ujedinjenih naroda protiv korupcije, Narodne novine, Međunarodni ugovori, br. 2/2005. 
Summary

Orsat Miljenić*

\section{THE CORRUPTION DEFENSE AND RESPONSIBILITY OF THE STATE IN INTERNATIONAL INVESTMENT LAW FOR CORRUPT ACTS OF ITS OFFICIALS}

The corruption defense is being used more and more frequently. International investment arbitral tribunals tend to accept it as a complete defense - if the state can prove that there was corruption connected with the establishment of an investment, the investor is denied protection of the relevant investment treaty. Such an approach, disregarding the fact that corruption is by its nature bilateral, punishes only one side - the investor, while the state is in a way immunized despite the fact that its officials, sometime even highest-ranking officials, were engaged in the same corrupt act. Such an asymmetrical approach to the responsibility for corruption of the state and of the investor is contrary to the rules of international law regarding the responsibility of states. The article presents an analysis of the relevant rules regarding the responsibility of states in general and specifically for corruption in international public law, and their application to international investment law, arbitral practice regarding the corruption defense and its development. Possible solutions by way of amending international investment law or by applying existing rules of international public law, namely the principle of acquiescence, are proposed.

Keywords: international investment arbitration, corruption defense, responsibility of states, attribution, acquiescence

Orsat Miljenić, Ph. D., Member of Parliament, Chairperson of the Judiciary Commitee of the Croatian Parliament, Hrvatski sabor, Trg Sv. Marka 6, Zagreb; orsatmiljenic@ gmail.com;

ORCID ID: orcid.org/0000-0002-9191-3344 
